\title{
THE ACTIVITY OF JUSTICE BODIES ON THE LEGAL EXPERTISE OF THE PROJECTS OF NORMATIVE LEGAL ACTS
}

\section{Khaydarali Mukhamedov}

professor, Department of Theory of the state and Law of Tashkent State University of Law. Tashkent city, Uzbekistan.

Email: x.muxamedov@tsul.uz

\section{Khujanazarov Azizjon Anvarovich}

Teacher, Department of Theory of the state and Law of Tashkent State University of Law. Tashkent city, Uzbekistan.

Email: a.xujanazarov@tsul.uz

\section{ABSTRACT:}

The article analyzes the legal examination of the draft regulatory act regulating social relations in society aimed at determining, amending or repealing legal norms as generally binding state guidelines, as well as the activities of the justice system in this area on a systematic basis based on national legislation. The article also developed copyright proposals on the concept, types, and principles of legal examination of the draft regulatory legal document.

Keywords: social, theory, system, justice, state, ministry, norm, expertise, structure, function, law, resolution.

Article Received: 18 October 2020, Revised: 3 November 2020, Accepted: 24 December 202

\section{INTRODUCTION}

One of the main ways to ensure the rule of law in almost all spheres of public life and ensure legality in the activities of state and economic management, local government bodies is to conduct legal expertise, first, the drafts of legislation issued by them.

Legal expertise of projects of normative legal acts is, in turn, one of the main institutions of the activity of normative creativity. After all, the rule of law in society and any kind of socialeconomic and legal relations arising are regulated based on relevant normative legal acts. Their compliance with high-standing legislation decides the legality of legislative acts.

\section{LITERATURE REVIEW}

Lawyer scientist M.K.Najimov described the concept of legal expertise as the activity of legal entities and individuals to conclude the point of view of their compliance with the accepted legal document or its draft constitution and legislation, as well as the established rules of legal technology[1].

The legal expert of the draft law is to assess the compliance of the draft law with the RF Constitution and its position in the system of current legislation and international treaties, as well as to check its quality and effectiveness of the rules of Legislative technique[2].

Also, the lawyer scientist X.Haitov said that the result of the expert or group of experts with special knowledge and skills on the concept of the expert of draft laws based on draft laws will be formalized in the form of a conclusion, identifying and eliminating the various shortcomings allowed in them, it has been described as an activity aimed at developing recommendations based on the evaluation of compliance of the draft laws with the legislative system, norms of international law, legislative techniques, the extent to which reforms are carried out in our country[3].

In Particular, E.V.Razd'yakonova and E.D.Tretyakova divided the following types of expertise:

- depending on the subjects carrying out expert activities: State, Public, International;

- by the stage of compLexity:

a )Essex (if a normative legal act or project relates to several areas of Legal Regulation); 
b) specialized (if the draft normative legal act relates to some sphere of regulated social relations) [4].

\section{METHODS}

Law scientist Z.M.Islamov proposed to research in the field of state and law based on the following methods:

1. The Concrete-sociological method often turns out to be the only correct one when studying various spheres of activity of legal and state institutions, when it is necessary to assess the effectiveness of decisions made, the timeliness and effectiveness of legal regulation or legal protection.

2. The Comparative legal method is no less important in the methodology of state and legal studies than the specific sociological method. The comparative method involves comparing concepts, phenomena and processes and finding out the similarities and differences between them. As a result of the comparison, the qualitative state of the legal system, the state structure as a whole, or individual, for example, legal institutions and norms are established.

However, it is important to take into account one condition: the objects to be compared must be comparable. Let's explain with examples. You can compare legal systems, state structures, and similar legal institutions and norms. But you cannot compare, for example, the legal system in General and individual legal norm of These objects is incomparable for the level, scope, contents and grounds.

3. Specifics and main functions of the legal method. Formal-legal (normative-dogmatic) can be rightly called traditional, characteristic of legal science, resulting from its nature. Its essence is that the law is studied as such: it is not compared to anything, it is not linked to the economy, politics, morality, or other social phenomena[5].

\section{DISCUSSION AND ANALYSIS}

Before studying the activities of the justice bodies on the legal expertise of drafts of normative legal acts, it is worthwhile to dwell on the concept and types of normative legal acts, which should be conducted through legal expertise, in accordance with the legal description.

In particular, the normative-legal document is an official document adopted by the law of the Republic of Uzbekistan "on normativelegal acts" of December 24, 2012[6], aimed at establishing, changing or abolishing legal norms as general mandatory state directives.

Following Article 5 of this law, the Constitution of the Republic of Uzbekistan, laws, resolutions of the chambers of the Oliy Majlis of the Republic of Uzbekistan, decrees and resolutions of the President, decisions of the Cabinet of Ministers, as well as orders and decisions of ministries, departments and agencies of the state and local authorities are normativelegal acts.

At the same time, if we dwell separately on the dictionary and legal description of the concepts" expertise "and" legal expertise", it can be expressed as follows.

Referring to the content and essence of the concept of " expertise", as defined in the Explanatory Dictionary of the Uzbek language on this concept, we can say that" expertise-(FR. expertise, a lot. experts-experienced; tested) is an organized examination with the participation of specialists to solve and solve a difficult or complex issue[7].

Also, Yu.V.Sidelnikov describes expertise as an evaluation-analysis activity carried out by involving experts to analyze and (or) evaluate objects of expertise to prepare materials for the justification of decisions made under conditions of partial uncertainty [8].

Also, following Article 22 of the law of the Republic of Uzbekistan "on normative-legal acts" of December 24, 2012, during the legal examination, compliance of the draft normativelegal document with the Constitution and laws of the Republic of Uzbekistan, other normative-legal acts having a higher legal force than it, with the 
rules of legislative technique, as well as the legal expertise, on the one hand, as one of the tools for assessing the effectiveness of legislation, on the other hand, is a separate subject of the study and a set of established methods, special subjects with the authority to conduct it, the result in the form of an expert opinion allows being considered as a legal institution with special characteristics, such as the place established by Legal Regulation mechanism [9].

Also, to prevent the occurrence of various violations in the life of the public administration system and society, as well as to determine the existence of rules that impose excessive restrictions on economic entities, it is desirable to carry out projects of normative legal acts by the print ships of legal expertise, legality, independence, knowledge, transparency, systematicity, and explain these:

- according to the principle of obligation, the draft normative-legal document by Article 21 of the law of the Republic of Uzbekistan "on normative-legal acts" dated December 24, 2012, is determined by the fact that it is necessary to conduct legal expertise;

- the content of the draft normative legal act on the printing of legality is expressed in compliance with the legislation having a higher legal force;

- independence printing is expressed in the implementation of this activity from the point of view of the independence of the experts in the evaluation of the draft normative-legal document by the established procedure in the legislation [10];

- the print of knowledge is expressed in the implementation of theoretical analysis by them in the sections of the sphere of the jurisprudence of projects of the normative-legal document on the conduct of legal expertise with the involvement of scientists and specialists;

- the transparency Print-Out can be indicated in the public discussion of projects of normative legal acts or the discussion of specialists, as defined in Article 20 of the new edition of the law" on normative legal acts". Proposals and proposals expressed during the discussion of the public and specialists should be considered by the main executive or working group (Commission) [11];

- by the Methodological instructions of the minister of Justice of the Republic of Uzbekistan approved by the order of the Ministry of Justice dated April 9, 2012, № 83 (list number $2352,09.04 .2012$ year) from the point of view of systematization (list number 2352, 09.04.2012 year), the draft normative legal document is conducted by the legal; after agreement with all interested bodies, the developer is sent to the Ministry of justice for legal expertise, having attached the relevant documents before entering the project into the Cabinet of Ministers of the Republic of Uzbekistan;

- the project shall be entered into the Cabinet of Ministers in the manner prescribed by the developer in the procedure established by the regulation of the Cabinet of Ministers in the manner prescribed by the Ministry of Justice after the conduct of legal expertise.

There are also various norms and approaches in the legal and theoretical literature in the classification of legal expertise of projects of normative legal acts.

In our opinion, it is desirable to classify the activities of legal expertise as follows, based on national legislation and local theoretical sources:

a) in the field of law: anti-corruption, gender-legal, international legal, criminological;

b) on authorized subjects: the legal service of the developer of projects of normative legal acts or the body authorized to accept such documents, as well as legal expertise conducted by the justice authorities;

c) by law: legal expertise of the law and legislation.

By the national legislation [12], the legal expertise of legislative acts, in turn, is divided into legal expertise, which is carried out by the legal 
service of the developer and the justice authorities of the project on the subjects.

From this, the draft normative-legal document is considered one of the main directions of the justice bodies in the activity of normative creativity, in ensuring the state legal policy in the field of normative creativity and conducting normative-legal projects from legal expertise, the justice bodies also occupy a key place in ourselves and other countries.

In the place of information, it should be noted that the implementation of the preliminary analysis of legislative projects and proposals by the authorities of Justice in our country, that is, the history of the introduction of the first manifestations of legal expertise into the system activities, began on May 6, 1925, with the approval of the dispute on the people's commissariat According to Paragraph 1 of the charter, the primary consideration of all proposals submitted to the central executive branch of Uzbekistan and the Council of the people's Commissariat of Justice on legislative issues; control over the enforcement of legislation; tasks such as interpretation of applicable laws are imposed on [13].

After gaining independence, the Ministry of Justice of the USSR of Uzbekistan was transformed into the Ministry of Justice of the Republic of Uzbekistan by the historical decree of the president of the Republic of Uzbekistan "on the improvement of the activities of the Ministry of Justice of the Republic of Uzbekistan" in the 1992 Year 8 January, and the ministries, state committees and departments, also, the ministry was entrusted with the tasks of making proposals on amendments to the legislation and making amendments to them on the issues raised at the disposal of the ministry and submitting them to the Presidium of the Supreme Council of the Republic of Uzbekistan.

In accordance with Article 22 of the law of the Republic of Uzbekistan "on normative legal acts" of December 24, 2012, in addition to the legal service of the developer or regulatory body, the legal expert of projects of normative legal acts is appointed by the Ministry of Justice of the Republic of Uzbekistan. The Ministry of Justice carries out legal expertise of projects of normative legal acts after conducting other types of expertise. The legal expertise of the projects of decisions of local government bodies is carried out by the relevant justice authorities.

The Ministry of Justice, the Ministry of Justice of the Republic of Karakalpakstan, the justice departments of the regions and Tashkent city, the districts (cities), the justice departments provide the conditions for the implementation of these projects during the legal expertise of the projects of normative legal acts in the system of state authorities and management bodies, also established that it will carry out its analysis from the point of view of determining whether some rules and norms impose excessive administrative restrictions as well as other restrictions that lead to unreasonable expenditure for business entities.

At the same time, the Ministry of Justice of the Republic of Uzbekistan during the legal expertise of projects of normative-legal documents:

- projects in accordance with the objectives and objectives of the reforms carried out in their country;

- to provide conditions for the occurrence of violations in the system of public authorities and management bodies;

- the rules and norms that introduce excessive administrative and other restrictions for business entities;

- carries out an analysis on the identification of rules that create unreasonable costs in business entities, complicate the process of carrying out entrepreneurial activities and impose new obligations on business entities, defining new measures of responsibility for them [14].

In accordance with the current regulation[15], the draft normative-legal document should be submitted to the Cabinet of 
Ministers, the administration of the president of the Republic of Uzbekistan only when there is a corresponding conclusion of the Ministry of Justice on the expediency of its adoption after the completion of a legal examination, also, the presence of a positive opinion of the justice authorities on the results of legal expertise is an obligatory condition for decision-making by local government bodies.

Within the framework of this activity, during the past period, i.e. in 2019, a total of 2754 projects of normative-legal documents were submitted to the Ministry of justice for legal expertise, of which 2541 were submitted to the conclusion of legal expertise (if 2178 projects were signed, the remaining 363 projects were not signed) and the remaining 213 projects were returned to the government regulation.

During this period, a total of 564 departmental normative legal documents were registered by the ministry and 159 departmental normative legal documents were rejected for registration.

In addition, for the conduct of legal expertise to the territorial justice authorities, a total of 1365 projects of decisions of local government bodies (1162 decisions of the governorship and 203 decisions of the council) were adopted in 2019, of which 1228 were signed, the remaining 137 were returned[16].

It is aimed to analyze the activities of the legal expert of the projects of normative legal acts carried out by the justice authorities by the procedure established by the national legislation in the following directions:

a) legal expertise of projects of the laws of the Republic of Uzbekistan, decrees, decisions and orders of the president of the Republic of Uzbekistan, decisions and orders of the Cabinet of Ministers;

b) legal expertise of the decisions of the Government minutes and departmental normative legal acts;

c) legal expertise of projects of decisions of local government authorities.

g) legal expertise of projects of international treaties.

Legal expert of projects of the laws of the Republic of Uzbekistan, decrees, decisions and orders of the president of the Republic of Uzbekistan, decisions and orders of the Cabinet of Ministers:

- the draft normative-legal document is submitted by the legal service of the developer of projects of the laws of the Republic of Uzbekistan, presidential decrees and decrees, decisions and orders of the Cabinet of Ministers or the body authorized to accept such documents, and after the agreement, the project is sent to the Ministry of justice for legal expertise.

In particular, in accordance with the law of the Republic of Uzbekistan "on the preparation of draft laws and the procedure for their inclusion in the Legislative Chamber of the Oliy Majlis of the Republic of Uzbekistan"adopted on October 11, 2006, after the completion of the work on the draft law, the project can also be conducted from legal and other (economic, financial, scientific, Experts present an appropriate conclusion on the results of the expert examination of the draft law.

During the conduct of the legal examination, the conformity of the norms of the draft law with the Constitution and laws of the Republic of Uzbekistan, the rules of the Legislative technique, as well as the validity and expediency of the application of the norms of the applicant are checked. Legal expertise of the draft law can be conducted by the legal service of the subject of the right of legislative initiative, as well as the Ministry of Justice of the Republic of Uzbekistan and other organizations in accordance with the legislation. In this case, the Ministry of Justice of the Republic of Uzbekistan carries out legal expertise of projects of laws after conducting other types of expertise [17].

In addition, the projects of decrees, decisions and orders of the president of the Republic of Uzbekistan, developed by the administration of the president of the Republic of 
Uzbekistan, shall be carried out within two days of the agreement with the relevant state bodies and other organizations and their legal expertise in the Ministry of Justice [18].

Minister of Justice of the Republic of Uzbekistan for 2012 in accordance with paragraph 110 of the methodological guidelines approved by the Order No. 83 of April 9 (List Number 2352, 09.04.2012 years), the draft normative-legal acts entered into the Cabinet of Ministers of the Republic of Uzbekistan by the state and economic management bodies and local government bodies after agreement with all interested bodies, before the inclusion of the:

a letter of clarification, in which the concept of law is explained, or a letter of clarification, which consists in substantiating the expediency of the draft of this normative legal act;

the legal conclusion signed by the head of the developer's legal service (jurisconsult in the absence of the position of head of the legal service). In the legal conclusion, it is necessary to specify the surname, name, patronymic, position, contact phone numbers of the person who signed it;

if it is envisaged to make changes and additions to other normative legal acts with the project, the comparative table should be; projects;

project development plan-schedule-for

proposals on the eligibility of international documents and legislation of foreign countries, relevant provisions of the legislation of the Republic of Uzbekistan, the application of relevant international experience in the conditions of the Republic of Uzbekistan provide for the analytical comparative table (if necessary for legislative documents);

the tables of disagreement, if the project is agreed (signed) by the interested bodies with proposals and Comments, shall contain copies of the letters expressed in the proposals and proposals of these bodies.;

having attached the schedule for consideration of proposals, the Republic of Uzbekistan sends to the Ministry of justice for the conduct of legal expertise.

Ministry of Justice of the Republic of Uzbekistan in accordance with the methodological instructions:

in order to determine the conformity of the projects with the Constitution and laws of the Republic of Uzbekistan, other normative-legal acts, rules of legislative technique, as well as the rationality and expediency of application of referential norms, conduct their legal expertise;

projects are designed to create conditions for their compliance with the goals and objectives of the reforms carried out in the country, for the commission of offences in the system of state authorities and management bodies, as well as introduce excessive administrative and other restrictions for the subjects of entrepreneurship, which entail unreasonable costs in business entities, complicate the process of carrying out entrepreneurial, carries out an analysis on the determination of the rules that determine the new measures of responsibility for them.

The Cabinet of Ministers of the Republic of Uzbekistan in accordance with the regulations of the Cabinet of Ministers approved by the resolution of March 22, 242, if the documents and instructions of the president of the Republic of Uzbekistan, the documents of the Cabinet of Ministers, the term of preparation of a legal conclusion in relation to the documents of the government should not be more than ten days, unless other periods of entry are established by the instructions of the prime minister, his deputies [19].

In paragraph 113 of the methodological guidelines, it is established that the project will be returned to the developer by the Ministry of justice without legal examination and analysis in the following cases:

in the event that the project is not agreed by all interested bodies at the level of their first heads (in exceptional cases - their first places; 
in the event that the documents specified in paragraph 110 of these methodological guidelines are not attached to the project.

According to the results of legal expertise of the project, the minister of Justice of the Republic of Uzbekistan (in exceptional cases the first place of the minister) signs the project. In the event that there are proposals and comments, the project will be signed with proposals and comments.

The project will be returned to the developer by the minister of Justice of the Republic of Uzbekistan or one of its seats, if:

the project contradicts the norms and principles of the Constitution of the Republic of Uzbekistan;

the project requires that changes, additions, additions to normative legal acts with a higher legal force be found to have lost their power, and it is not provided as a project that implies that changes, additions to the relevant normative legal acts are found to have lost their power;

since the issues envisaged in the project are regulated by normative legal acts having equal or higher legal force, there is no need for the adoption of a normative legal act;

the project should be completely processed due to the abundance of proposals and proposals, including serious (congestive) shortcomings, that is, the project should be processed taking into account these proposals and proposals, which will lead to a radical change in its content and require a re-agreement with the concerned ministries and departments.

The relevant authorities and proposals on the project are indicated in the single electronic system of development and agreement of normative legal acts and approved by the minister of Justice of the Republic of Uzbekistan or one of its deputies.

In accordance with the methodological instructions of the project, the developer shall enter into the Cabinet of Ministers of the Republic of Uzbekistan in the manner prescribed by the regulation of the Cabinet of Ministers in the manner prescribed by the Ministry of Justice after the conduct of legal expertise.

b) legal expertise of government statement decisions and departmental normative legal acts.

The Department of "state registration of departmental normative-legal acts" of the Ministry of Justice[20] conducted from the state list of normative-legal acts(legal expertise)of the ministry, departments and departments [21].

This department was established by the decree of the president of the Republic of Uzbekistan № PP-3666 of April 13, 2018 as the "Department for legal expertise of government declaration decisions and departmental normative documents". According to the order of the minister of Justice of the Republic of Uzbekistan dated May 4, 2018 № 134, the following are the main tasks of the Department:

- transfer of departmental normativelegal documents from the point of view of determining the compliance of legislation, norms of international treaties, goals and objectives of the reforms carried out in the country, rules of legislative technique, conditions for their commission of offences, as well as rules and norms that impose excessive administrative and other restrictions on individuals and legal entities;

- legal expertise in terms of identifying national guidelines, including guidelines providing for individual preferences and preferences, in the draft government declaration decisions [22].

O lawyer scientist about it.In his research work, the proposal of the president of the Republic of Uzbekistan on the implementation of the practice of legal expertization in the Ministry of Justice of the Republic of Uzbekistan "on organizational measures for further improvement of the activities of the Ministry of Justice of the Republic of Uzbekistan" PP-3666 of April 13, 2018 " was reflected in Paragraph 2, also, this proposal of the researcher contributed to the nonestablishment of legal norms in government 
declarations as well as to the reliable protection of the rights and interests of individuals and legal entities [23].

The Cabinet of Ministers of the Republic of Uzbekistan The regulation of the Cabinet of Ministers of the Republic of Uzbekistan[24] approved by the resolution of March 22, 242, defines that the projects of government declaration decisions must be conducted legal expertise in a mandatory manner, and the Ministry of Justice shall ensure the implementation of government declaration decisions.

In particular, according to the regulation, within 1 day after the end of the meeting of the Cabinet of Ministers, the responsible body, that is, the developer, develops the draft resolution of the Cabinet of Ministers (with the exception of declarations of the Presidium of the Cabinet of Ministers), sends to the Ministry of justice for legal expertise.

Within 1 day from the date of receipt of the project, the Ministry of Justice conducts legal expertise in terms of the availability of norms that provide for the issuance of nationwide instructions, including individual preferences and preferences, and, as a result, sends the developer a conclusion on the project.

Within 1 day after the legal examination, the developer of the project, in case of receipt of proposals and proposals from the Ministry of justice, processes the project and submits it to the Cabinet of Ministers. Within 1 day after the project is entered into the Cabinet, the structural unit of the apparatus of the Cabinet of Ministers prepares for approval of the project.

Within 1 day after approval in accordance with the instructions of the leadership of the Cabinet of ministers, the structural unit of the apparatus of the Cabinet of Ministers shall enter the project for approval to the Prime Minister of the Republic of Uzbekistan or to its seats, and shall send the decision of the Cabinet of Ministers to the Ministry of Justice

Within 1 day after the decision of the
Cabinet of ministers falls, the Ministry of Justice shall take into account the decision of this declaration.

The departmental normative-legal document is an official document (orders and decisions) that is adopted in the manner prescribed by the ministry, the state branch and the office, aimed at establishing, changing or abolishing legal norms as general mandatory state directives [25].

Legal expertise of the departmental normative-legal document - this departmental normative-legal document is subject to the Constitution and laws of the Republic of Uzbekistan, other legislation having a higher legal force in relation to it carry out the verification of the conformity of the reforms carried out in the country to the goals and objectives, the rules of the legislative technique, as well as the rationality and expediency of the application of the norms of reference.

According to O.Fayziev, the departmental normative-legal document is a document issued by the ministry, the state agency or the office within the framework of its powers and in order to carry out the functions assigned to it, to ensure activities in the relevant spheres of management and social life a high standing is a normative legal document, which is based on normative legal acts and is adopted for their execution[26].

The orders are taken by the ministers or by the heads of departments, where decisions on behalf of the office are made individually. Decisions are taken by the state bodies or by the bodies that carry out the decisions on behalf of the administration, the collegial body of this office. Departmental normative-legal acts of two or more ministries and departments are adopted in the manner of decisions.

State registration of departmental normative-legal act:

a) legal expertise;

b) to make a decision on the state registration of this act;

C) to enter into the State Register of departmental normative-legal acts (hereinafter 
referred to as the state register) a record on the state registration of the departmental normativelegal document with the registration number given in the text and to include it in the State Register;

g) to include in the state register a record of the loss of its power of the departmental normative-legal act and the issuance of it from the State Register.

Lawyer scientist a.Fayziev defined in departmental normative-legal acts the existence of rules and norms that create conditions for corruption, other violations in the system of state power and management bodies, and the second, which establishes responsibility for citizens and business entities the determination of the existence of rules and norms that impose unreasonable costs, excessive administrative and other restrictions have been cited as separate rules that focus on the conduct of legal expertise of departmental normative legal documents [27].

Legal expertise of projects of decisions of local government bodies.

It is known that the presence of a positive opinion of the territorial justice authorities on the results of the legal examination is an obligatory condition for the adoption of normative legal acts by local state authorities [28].

The decision of the local state authority on the normative-legal character is an official document adopted by the Regional, District, City Councils of people's deputies and khokims of the region, district, city, aimed at establishing, amending or abolishing legal norms as nationwide state directives [29].

If the project establishes a legal norm that has even one nationwide character, such a project must necessarily undergo legal expertise in the territorial justice authorities.

The folding systemic rules of legal expertise of the craft vision of the local state authority on the regulatory-legal character are laid down by the regional justice bodies:

- a certificate prepared by the project, documents on the agreement of the project and a letter of observation signed by the governor or his place of residence will be submitted to the regional justice authority for legal expertise;

The folding systemic rules of legal expertization of the craftisision of the local state authority on the regulatory-legal character are laid down by the regional justice bodies:

- a certificate prepared by the project, documents on the agreement of the project and a letter of observation signed by the governor or his place of residence will be submitted to the regional justice authority for legal exposure;

a) if the project does not have a normativelegal nature;

b) if the project is not agreed by all interested bodies at the level of their first heads (in exceptional cases - their first places;

c) if the above-mentioned documents have not been attached to the project;

d) if the reference does not reflect the fact that the project was conducted through public discussion and the information on its results.

Legal expert of projects of international treaties implemented by the Ministry of Justice of the Republic of Uzbekistan.

This activity is carried out by the Department of "international legal cooperation" of the ministry through establishing, and strengthening international legal cooperation, conducting legal expertise of international agreements.

The international treaty of the Republic of Uzbekistan-regardless of whether it consists of one document, two or several documents related to each other, as well as its specific name and method of formation (contract, agreement, Convention, ICT, pact, declaration, exchange of letters or notes, as well as different names and methods of formation of the international treaty), the international agreement concluded by the Republic of Uzbekistan in writing with a foreign state, international organization or other subject having the right to conclude international agreements, regulated by international law[30]. 
During the past 2019, the Ministry of Justice of the Republic of Uzbekistan conducted a total of 469 legal expertise on projects of international treaties (290 for 2018, 206 for 2017) and issued a legal conclusion [31].

During the past 2019, the Ministry of Justice of the Republic of Uzbekistan conducted a total of 469 legal expertises on projects of international treaties (290 for 2018, 206 for 2017) and issued a legal conclusion [31].

\section{CONCLUSION}

The research outputs on the legal expertise of the normative legal act and the deep analysis of the current legislation of the judicial authorities demonstrate that there is an indeed necessity for further improvement in this area. So, it is highly recommended to conduct developing measures systematically. In particular, the following suggestions may definitely give an impulse to the perspective future of the area:

First, the legal expert of the draft normative legal act is the legal service of the developer of draft legislative acts or the body authorized to accept such documents, it also covers the comprehensive study of the draft normative-legal act by the justice authorities in terms of compliance with other legislation having a higher legal force with it and the rules of normative creativity techniques, as well as the conclusion of the result in accordance with the established procedure.

Second, in order to prevent the occurrence of various violations in the life of the public administration system and society, as well as to determine the existence of rules that impose excessive restrictions on economic entities, it is desirable to carry out projects of normative legal acts in accordance with the print-outs of legal expertise in accordance with the print-outs of necessity, legality, independence, knowledge, transparency, systematicity.

Third, it is desirable to classify the activity of legal expertise based on national legislation and local theoretical sources, on the areas of law, on authorized subjects, on legislative acts.

Fourth, according to the current national legislation, the legal expertise of normative legal acts, in turn, is divided into legal expertise, which is carried out by the legal service of the developer and the justice authorities of the project on the subjects.

\section{ACKNOWLEDGMENTS}

We would like to express our deep gratitude to Prof. M. Najimov for his valuable assistance to conduct the research. Furthermore, we also thank the other professors of the Department of Theory of the state and law of TSUL for providing scientific material.

\section{References}

[1] Najimov M.K. The lawmaking. The textbook. - Tashkent: TDYOU, 2018. - p. 77.

[2] Skorka E.V. Nekatorie Vaprosi integrasii ekspertnogo znaniya $\mathrm{v}$ zakonodatelnuyu deyatelnast / / Predstavitelnaya vlast - XXI vek: zakonodatelstva, kommentarii, problemi,2002.№ 2-3.- p. 46,

[3] Khayitav X.S. Improvement of organizational and legal basis of expert examination in the creativity of the law. Doctor of Legal Sciences (DSc) ... the dis.authorship. T.: 2018. - p. 14.

[4] Razd'yakonova E.V., Tretyakova, E.D. Pravovaya ekspertiza normativnix pravovix aktov:Uchebnoe posobie / avtori E.V.Razd'yakonova, E.- D. S. Tretyakova; SIU-branch Ranhigs. - Novosibirsk: izd-vo Sibags.-2014.- p. 54.

[5] Islamav Z.M. Problemi teorii gosudarstva I prava sovremennosti. Uchebnik. - T.: TGYUI, 2006. - p. 10.

[6] Collection of legislation of the Republic of Uzbekistan, 2012 y., Article 52, article 583. 
[7] Explanatory Dictionary of the Uzbek language: more than 80000 words and combinations of words. C. 5. "E" / editorial board: T.Mirzaev (leader) and others.; UZR FA language and literature institute. - T.: State Scientific Publishing House "National Encyclopedia of Uzbekistan", 2006. - p. 27.

[8] Sidelnikov Yu.V. Expertise: sastoyanie I razvitiya trend / / Mirovaya ekonomika I mecdunaradnie otnosheniya. -1997. -№ 2. p. 23.

[9] Yuridicheskaya ekspertiza normativnix pravovix aktov: Uchebnoe posobie / sost.: G.no, it's not.what?, associate professor D.Sh. Pirbudagova i dr.. 2-e izd., pererab. i dop. Makhachkala: Izd-vo DGU, 2017. - p. 14.

[10] Collection of legislation of the Republic of Uzbekistan, 2012 y., Article 52, article 583.

[11] Collection of legislation of the Republic of Uzbekistan, 2012 y., Article 15, Article 173.

[12] Collection of legislation of the Republic of Uzbekistan, 2012 y., Article 52, article 583. https://www.minjust.uz/uz/about/history/

[13] Collection of legislation of the Republic of Uzbekistan, 2012 y., Article 15, Article 173. National database of legislation data, 14.04.2018 y., 07/18/3666/1073-San. https://www.minjust.uz/uz/activity/normacti vity/98766/

[14] collection of legislation of the Republic of Uzbekistan, 2006 Article 41, article 406. https://nrm.uz

[15] National database of legislation data, 25.03.2019 y., 09/19/242/2820-th; 18.02.2020 у., 09/20/88/0178-San

[16] National database of legislation data, 14.04.2018 y., 07/18/3666/1073-San.

[17] Collection of legislation of the Republic of Uzbekistan, 2012 y. Article 329.https://www.minjust.uz/uz/about/appara t/

[18] Feyziev A.R Increase the effectiveness of legal expertise and state registration of orders and decisions of ministries, government departments and agencies. Doctor of Philosophy $(\mathrm{PhD}) \ldots$ the dis.authorship. T.: 2018. - p. 11-12.

[19] National database of legislation data, 25.03.2019 y., 09/19/242/2820-San.

[20] Collection of legislation of the Republic of Uzbekistan, 2014 y., Article 10, Article 110.

[21] Feyziev A.R Increase the effectiveness of legal expertise and state registration of orders and decisions of ministries, government departments and agencies. Doctor of Philosophy (PhD)... the dis.authorship. T.: 2018. - p. 13.

[22] Feyziev A.R Increase the effectiveness of legal expertise and state registration of orders and decisions of ministries, government departments and agencies. Doctor of Philosophy $(\mathrm{PhD}) \ldots$ the dis.authorship. T.: 2018. - p. 16.

[23] National database of legislation data, 14.04.2018 y., 07/18/3666/1073-San.

[24] Collection of legislation of the Republic of Uzbekistan, 2013., 5-San, Article 65.

[25] National database of legislation data, 07.02.2019 y., 03/19/518/2589-number. www.huquqiyportal.uz 